\title{
Bioaccumulation of Mercury by Bacteria Isolated from Small Scale Gold Mining Tailings in Lombok, Indonesia
}

\author{
Siska Nurfitriani ${ }^{*}$, Endang Arisoesilaningsih ${ }^{2}$, Yulia Nuraini ${ }^{3}$, Eko Handayanto ${ }^{3}$ \\ 1 Postgraduate Programme, Faculty of Agriculture, Brawijaya University, Jl. Veteran No.1, Malang 65145, \\ Indonesia \\ 2 Department of Biology, Faculty of Mathematics and Natural Sciences, Brawijaya University, Jl. Veteran No.1, \\ Malang 65145, Indonesia \\ 3 Department of Soil Science, Faculty of Agriculture, Brawijaya University, Jl. Veteran, Malang 65145, Indonesia \\ * Corresponding author: siskanurfitriani94@gmail.com
}

\begin{abstract}
The activity of small scale gold mining (ASGM) in Indonesia has expanded to Lombok Island, West Nusa Tenggara. The use of mercury $(\mathrm{Hg})$ and the traditional mining process cause that the ASGM tailings waste still contains $\mathrm{Hg}$. The tailings waste is piled up near paddy fields and residential areas so that it has the potential to pollute the environment. This study aimed at isolating the bacteria that can accumulate Hg from the ASGM tailings in Lombok. The tailing samples were taken from Sekotong, Pujut, and Jonggat Districts, Lombok. The bacteria that have been isolated from the tailing samples were tested for their ability of $\mathrm{Hg}$ hemolysis resistance, and $\mathrm{Hg}$ bioaccumulation. Three bacteria with the highest $\mathrm{Hg}$ bioaccumulation ability were identified using the 16S rDNA gene squad. The results showed that out of 32 bacterial isolates, 27 isolates were found to be tolerant to $\mathrm{Hg}$. Two bacterial isolates that were able to accumulate the highest amount of $\mathrm{Hg}$ and were identified as Fictibacillus nanhainensis (SKT-B) $82.25 \%$ and Bacillus toyonensis (PJM-F1) 81.21\%. This study proved that the bacteria isolated from ASGM tailings have a great potential to be used as $\mathrm{Hg}$ bioaccumulation agents.
\end{abstract}

Keywords: $\mathrm{Hg}$ resistant bacteria, $\mathrm{Hg}$ bioaccumulation, small scale gold mine tailings

\section{INTRODUCTION}

Small Scale Gold Mining (ASGM) activities are increasing in many low and middle-income countries, one of which is Indonesia (Basu et al., 2015). One of the islands in Indonesia that is the location of ASGM is Lombok, West Nusa Tenggara (Krisnayanti et al., 2012). The gold mining in Lombok is carried out using the amalgamation and cyanidation methods (Muddarisna et al., 2013). However, in some areas in Lombok, such as Sekotong, miners use the amalgamation method to separate gold from tailings (Utomo et al., 2014). In the amalgamation method, gold is extracted from gold ore using 'gelondong' (small iron cylindrical tubes) and mercury $(\mathrm{Hg})$ (Krisnayanti, 2018). The traditional mining process causes an increase of the $\mathrm{Hg}$ contamination from tailings to the environment. Every gram of gold produced through the amalgamation process releases $1-3 \mathrm{~g}$ of $\mathrm{Hg}$ into the environment through the tailings that are piled around the mining sites (Krisnayanti et al., 2012). Hg is one of the toxic elements that negatively affect the quality of the soil environment. The presence of $\mathrm{Hg}$ in the soil environment is associated with the presence of this metal in the lithosphere. Hg is present in very small amounts, but it can pose a threat to the animal and human organisms (Małuszyński et al., 2019). The human activities are increasing the heavy metals concentration in the ecosystem (Tjahjono and Suwarno, 2018).

Bioremediation is one of the remediation techniques that are considered to be more environmentally friendly than others (Ojuederie and Babalola, 2017). Besides, microbes are known 
to be able to live under extreme conditions. The community of bacteria reflects the relationship between diversity and environmental factors (Fagorzi et al., 2019). The bacteria that live in tailings have various mechanisms to protect themselves from the $\mathrm{Hg}$ toxicity, one of which is accumulation. Through the accumulation mechanism, the concentration of $\mathrm{Hg}$ in the bacterial cell tissue is higher than that in the environment in which it grows. This is because the metabolism and excretion of $\mathrm{Hg}$ from the bacterial body are slower than the absorption of $\mathrm{Hg}$. As a result, $\mathrm{Hg}$ accumulates in the body of bacteria (Puspitasari, 2007).

Several studies have been conducted to explore the types of bacteria that can live in the soils with high $\mathrm{Hg}$ concentrations. Irawati et al., (2017) reported that the Brevundimonas sp. bacteria isolated from the ASGM soil in Pongkor Village, Bogor was able to accumulate $2.7 \mathrm{mg} \mathrm{Hg} \mathrm{g}^{-1}$ of the bacterial dry weight. Other bacteria found in the Sekotong District, Lombok by Chasanah et al., (2018) were able to accumulate $74.2-76.1 \%$ $\mathrm{Hg}$ in the Nutrient Broth (NB) medium enriched with $\mathrm{HgCl}_{2}$ in the laboratory. Bacillus subtilis and Burkholderia cenosepacia isolated from the West Kalimantan ASGM tailings can accumulate $\mathrm{Hg}$ in their cells (Ekyastuti and Rima, 2015). This study aimed at elucidating the accumulation of $\mathrm{Hg}$ by the bacteria isolated from the ASGM tailings in Lombok.

\section{MATERIALS AND METHODS}

\section{Tailing Samples}

The tailings samples for bacterial isolation were collected from three gold processing sites in Lombok (Table 1) at a depth of $0-5 \mathrm{~cm}$ (Kuterbekov, 2019). The tailing samples were analyzed for $\mathrm{pH}$ (Moore, 1968), organic carbon content (Walkley and Black, 1934), organic matter content (Waksman and Stevens, 1930), available P content (Olsen et al., 1954), total $\mathrm{N}$ content (Kjeldahl, 1883), and total $\mathrm{K}$ content (Affinih et al., 2014). The results of the sample analysis are presented in Table 3.

\section{Bacterial Isolation}

Isolation was carried out on Nutrient Agar (NA) medium using serial dilution and Pour Plate methods up to $10^{-7}$ dilution series. The culture was incubated for 48 hours. The bacterial colonies that grew on each Petri were counted. The total bacterial population was calculated using the following formula (Husen et al., 2007):

$$
\text { Total bacteria }\left(\mathrm{CFU} \mathrm{g}^{-1}\right)=\frac{\text { total colony } \mathrm{x} \text { fp }}{\text { soil weight }}
$$

where: $f p=$ dilution factor in Petri dishes whose colonies are counted

Table 1. Description of the study location

\begin{tabular}{|c|l|c|l|l|l|}
\hline No & \multicolumn{1}{|c|}{ Location } & $\begin{array}{c}\text { District } \\
\text { Code }\end{array}$ & \multicolumn{1}{|c|}{ Coordinate } & $\begin{array}{l}\text { Status of tailings } \\
\text { collection }\end{array}$ & Vegetation / Land Use \\
\hline 1. & $\begin{array}{l}\text { Sekotong Tengah village, } \\
\text { Sekotong District, West Lombok }\end{array}$ & SKT & $\begin{array}{l}8^{\circ} 44^{\prime} 49.43^{\prime \prime} \mathrm{S} \\
115^{\circ} 57^{\prime} 43.69^{\prime \prime} \mathrm{E}\end{array}$ & Not active & $\begin{array}{l}\text { Meadows and tailings } \\
\text { ponds }\end{array}$ \\
\hline 2. & $\begin{array}{l}\text { Mawun Street, Mount Prabu } \\
\text { Village, Pujut District, Central } \\
\text { Lombok }\end{array}$ & PJT & $\begin{array}{l}8^{\circ} 53^{\circ} 27.00^{\prime \prime} \mathrm{S} \\
116^{\circ} 14^{\prime} 54.00^{\prime \prime} \mathrm{E}\end{array}$ & Active & Without vegetation \\
\hline 3. & $\begin{array}{l}\text { Batu Guling Street, Bonjeruk } \\
\text { village, Jonggat District, Central } \\
\text { Lombok }\end{array}$ & JGT & $\begin{array}{l}8^{\circ} 38^{\prime} 26.39^{\prime \prime} \mathrm{S} \\
116^{\circ} 13^{\prime} 23.20^{\prime \prime} \mathrm{E}\end{array}$ & Not active & $\begin{array}{l}\text { Tegalan, irrigated rice } \\
\text { fields, and freshwater } \\
\text { fish farming ponds }\end{array}$ \\
\hline
\end{tabular}

Table 2. Chemical properties of tailings

\begin{tabular}{|c|c|c|c|c|c|c|c|c|c|c|}
\hline \multirow{2}{*}{ No } & \multirow{2}{*}{ District } & \multicolumn{2}{|c|}{$\mathrm{pH}$} & \multirow{2}{*}{$\begin{array}{c}\text { C-Organic } \\
(\%)\end{array}$} & \multirow{2}{*}{$\begin{array}{c}\text { N Total } \\
(\%)\end{array}$} & \multirow{2}{*}{$\mathrm{C} / \mathrm{N}$} & \multirow{2}{*}{$\begin{array}{c}\text { Organic } \\
\text { Matter } \\
(\%)\end{array}$} & \multirow{2}{*}{$\begin{array}{l}\text { P-Olsen (mg/ } \\
\text { Kg) }\end{array}$} & \multirow{2}{*}{$\mathrm{K}(\mathrm{me} / 100 \mathrm{~g})$} & \multirow{2}{*}{$\mathrm{Hg}(\mathrm{ppm})$} \\
\hline & & $\mathrm{H}_{2} \mathrm{O}$ & $\mathrm{KCl}$ & & & & & & & \\
\hline 1 & JGT & 7.2 & 7 & 0.24 & 0.03 & 7 & 0.42 & 11.69 & 0.56 & 23.19 \\
\hline 2 & PJT & 8.1 & 7.6 & 0.16 & 0.03 & 6 & 0.28 & 29.13 & 0.28 & 9.87 \\
\hline 3 & SKT & 7.3 & 7.2 & 0.08 & 0.03 & 3 & 0.14 & 43.46 & 0.3 & 15.69 \\
\hline
\end{tabular}

Remarks: JGT: Jonggat; SKT: Sekotong; PJT: Pujut 
Table 3. Identification of isolated bacteria with the highest $\mathrm{Hg}$ bioaccumulation ability

\begin{tabular}{|c|l|c|c|}
\hline \multirow{2}{*}{ No. } & \multirow{2}{*}{ Parameter } & \multicolumn{2}{c|}{ Isolate code } \\
\cline { 3 - 4 } & & PJM-F1 & SKT-B \\
\hline 1. & Colour of the colony at TSA & 2,29 & Beige \\
\hline 2. & Colony diameter $(\mathrm{mm})$ & Circular & Circular \\
\hline 3. & Colony form & Undulate & Entire \\
\hline 4. & Colony margin & Convex & Convex \\
\hline 5. & Colony Elevation & wet & net \\
\hline 6. & Colony consistency & negative \\
\hline 7. & Gram reaction & Rod & Rod \\
\hline 8. & Sel form & Motil & - \\
\hline 9. & Motility & - & - \\
\hline 10. & Oxidase & - & + \\
\hline 11. & Catalase & + & - \\
\hline 12. & Indol production & Alk/As & Alk/As \\
\hline 13. & Use of carbon from citrate & - & - \\
\hline 14. & TSIA test & + & + \\
\hline 15. & Oxidase & & \\
\hline 16. & Motility & & \\
\hline
\end{tabular}

Remarks: Alk / As (lactose or sucrose fermentation)

Morphology of the bacterial colonies was identified based on the Bergey's Manual Determinative of Bacteria system.

\section{Bacterial Tolerance Test}

The bacterial tolerance test was carried out in Nutrient Agar (NA) enriched with $\mathrm{HgCl}_{2}$ (Irawati et al., 2013) according to treatment, namely $0 \mathrm{ppm}$ (control), 25, 50, 75, 100, and $125 \mathrm{ppm}$ using the streak method plates. The bacterial isolates were incubated for 14 days. The colonies that are resistant to $\mathrm{Hg}$ will grow and form new colonies on the streak line (Ekyastuti and Setyawati, 2015).

\section{Bacterial Pathogenicity Test}

The bacterial pathogenicity test was used to determine the potential of bacterial pathogenicity through its ability to dissolve blood. The pathogenicity test was carried out on the Blood Agar medium (Tryptic Soy Agar (TSA) medium enriched with $5 \%$ sheep blood) using the streak plates method and incubated for 24 hours. The observation of the ability of bacterial hemolysis was carried out over 24 hours. The bacteria are capable of hemolyzing blood if a clear zone ( $\beta$ hemolysis) or media discolouration ( $\alpha$ hemolysis) around the colony turns to green or brown (Buxton, 2005). The bacteria that are unable to hemolyze blood $(\gamma$ hemolysis) were used in further tests.

\section{Bacterial growth curve}

The bacterial isolates that were unable to hemolyze blood were tested for their growing ability on the Luria Bertani (LB) medium enriched with $\mathrm{HgCl}_{2}$. The bacteria that have been made inoculum stock were transferred to $25 \mathrm{~mL}$ of $\mathrm{LB}+\mathrm{HgCl}_{2}$ medium with a new dose of $125 \mathrm{ppm}$ with a concentration of $10 \%(\mathrm{v} / \mathrm{v})$. The culture was incubated for $24 \times 5$ hours in the shaker (Irawati et al., 2013; Ekyastuti and Setyawati, 2015). The bacterial growth was observed every 24 hours by measuring the cell density using a spectrophotometer at a wavelength of $600 \mathrm{~nm}$. The bacterial growth test in enriched media was repeated three times. The changes in the colour of bacterial colonies grown on $\mathrm{HgCl}_{2}$ enriched medium and without $\mathrm{HgCl}_{2}$ were also observed (Irawati et al., 2013).

\section{$\mathrm{Hg}$ accumulation test}

The Hg accumulation test was carried out on $25 \mathrm{~mL}$ of LB medium enriched with $125 \mathrm{ppm}$ $\mathrm{HgCl}_{2} .2 .5 \mathrm{~mL}$ of bacterial inoculum stock was added to $25 \mathrm{ml} \mathrm{LB}$. The accumulation test of each bacterial isolate was repeated three times (Irawati et al., 2013). The culture was incubated for $24 \mathrm{x}$ 5 hours at room temperature. The culture was observed on the fifth day or at the $120^{\text {th }}$ hour. The culture inoculum was shaken using a centrifuge 
at $10,000 \mathrm{rpm}$ with a temperature of $4^{\circ} \mathrm{C}$. The precipitate and supernatant from the culture were separated. The supernatant was transferred to a sterile test tube to measure the $\mathrm{Hg}$ concentration using an Atomic Absorption Spectrometer. The level of Hg accumulation by bacteria was determined through the formula (Ekyastuti and Setyawati, 2015). The ability of bacterial accumulation of each isolate was distinguished based on the percentage of bioaccumulation. Two isolates with the highest accumulation ability were selected for use in the next research stage.

$$
\begin{gathered}
\text { Bioaccumulation (\%) }= \\
=\frac{\text { total Hg of bacterial isolate }}{\text { total Hg in growing medium }} \times 100 \%
\end{gathered}
$$

\section{Identification of potential bacterial species from tailings}

Three selected bacterial isolates were identified through the biochemical and molecular tests using the 16S rDNA gene squad (Irawati et al., 2013; Cappuccino and Welsh, 2017). The identification was carried out on pure bacteria aged 24 hours using the Quick-DNA Fungal or Bacterial Microprep Kit (Zymo research corp., Tustin, USA). The extracted pure DNA was sent to Genetics Science Jakarta and $1^{\text {st }}$ Base, Selangor Malaysia for identification. After the $16 \mathrm{~S}$ rDNA gene from the bacteria was identified, the gene squad was entered into the Basic Local Alignment Search Tool (BLAST) which can be accessed through the National Center for Biotechnology Information (NCBI) website to identify the matches between the gene squares obtained. The final results from BLAST were matched with names or species in GenBank (Sanjay et al., 2018).

\section{RESULTS AND DISCUSSION}

\section{Total bacterial population}

The three gold processing districts have different bacterial populations. The highest bacterial population was obtained from Jonggat District (JGT) tailings with a total of $8.50 \times 10^{7} \mathrm{CFU}$, followed by Sekotong District (SKT) tailings of 1.93 x $10^{6} \mathrm{CFU}$, and Pujut District (PJT) tailings of 1.46 x $10^{6}$ (Figure 1). The difference in bacterial populations is related to the different condition of the tailings in the three districts (Table 1). Bacteria are sensitive indicators for determining the changes in organic matter and other chemical properties in soil. Adoption of a different management system can have a negative or positive effect on the chemical properties of the soil (Araujo et al., 2012).

The chemical properties of soil affect the total bacterial population (Rao, 1977). The results of chemical analysis of tailings from the three districts showed different results. The tailings from Jonggat (JGT) has organic carbon (C-organic), total nitrogen $(\mathrm{N})$, phosphorus $(\mathrm{P})$, and exchangeable potassium (K) higher than others (Table 3 ). Carbon, nitrogen, and phosphorus are important elements that support the bacterial growth and metabolism, so the presence of these elements greatly affects the bacterial population (Lay and Hastowo, 1992; Subandi, 2014). Organic carbon is a source of carbon and energy for bacteria. The decomposition of complex organic materials into simpler organic materials or inorganic materials will produce energy in the form of ATP. The energy produced by the bacteria from the decomposition process will be used in the synthesis of macromolecules, such as nucleic acids, lipids, and polysaccharides (Lay and Hastowo, 1992).

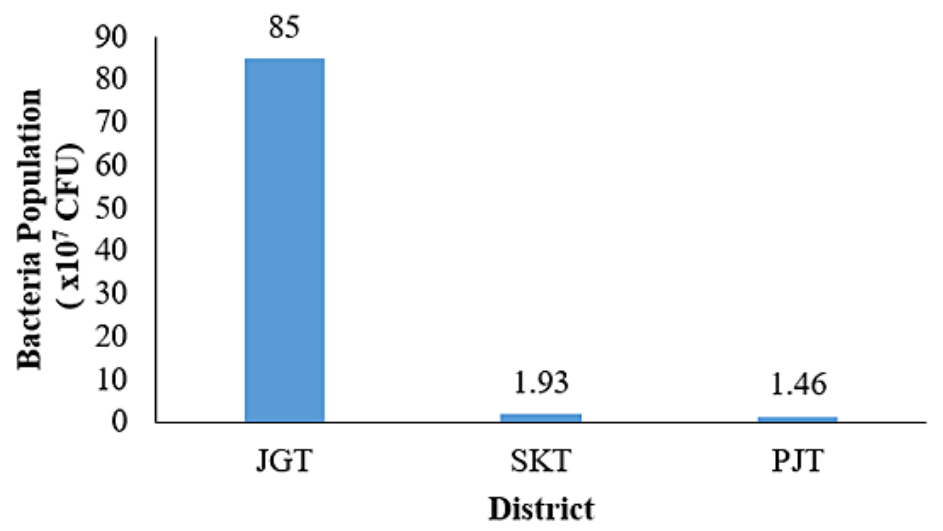

Figure 1. The total bacterial population in tailings. JGT: Jonggat; SKT: Sekotong; PJT: Pujut 
The formation of nucleic acids (RNA and DNA) in cells requires nitrogen and phosphorus. Nitrogen also plays a role in the formation of proteins responsible for the activity of cell metabolism and phosphorus needed in the synthesis of highenergy organic compounds such as ATP (adenosine triphosphate) (Subandi, 2014).

Cellular metabolism in bacteria also requires other elements in the form of minerals, such as potassium (Subandi, 2014). Potassium is the main intracellular cation in bacteria as well as in eukaryotic cells. The potassium absorption in cells is regulated by the ion and turgor concentrations. Potassium acts as a signal giver in the cytoplasm, activating and/or inducing the enzymes and transportation systems that allow cells to adapt to increased osmolarity (Epstein, 2003). Potassium is obtained by bacteria from basic compounds in the soil, so its availability greatly affects the bacterial population (Subandi, 2014).

The Hg concentration (Table 2) is directly proportional to the bacterial population (Figure 1). The Jonggat District tailing with the highest concentration of $\mathrm{Hg}$ has the highest bacterial population and vice versa. The results of this study differed from the previous studies that have been conducted. Most of the results showed that the bacterial population was negatively affected by the $\mathrm{Hg}$ concentration. The bacterial population and protozoa will decrease with the increase of the $\mathrm{Hg}$ concentration (Muller et al., 2001). Hg has been shown to negatively affect the conjugate transfer to plasmid (Rasmussen et al., 2008). However, considering the long history of the $\mathrm{Hg}$ contamination and the low concentration of the bioavailable $\mathrm{Hg}$, a plausible explanation for the high diversity of the Hg-resistant population is a horizontal transfer of mobile genetic elements carrying the mer-operon (Rasmussen et al., 2008). This results in the formation of bacteria that are tolerant of $\mathrm{Hg}$, contributing to high bacterial populations in contaminated soil.

\section{The tolerance ability of isolates to $\mathrm{Hg}$}

There were 27 isolated bacterial isolates that could tolerate $\mathrm{Hg}$ at a test dose of $125 \mathrm{ppm}$ (Figure 2). The ability of bacteria to tolerate $\mathrm{Hg}$ is because bacteria have the mer-operons that contain the encoding genes that can make the bacteria tolerant and have different mechanisms for adapting to the $\mathrm{Hg}$ stress (Ianieva, 2009).

The genes encoded by the mer-operons can be found in plasmids, chromosomes, transposomes, and integrins. Cellular elements (plasmids, transposons, and integrons) play an important role in the spread of mercury resistance throughout the microbial community through horizontal transfer. In addition, the resistant bacteria can also effectively transfer phenotypes (Hg resistant genes) to potentially pathogenic species (Morel et al., 1998; Kahl, 2015). This causes the mechanism of resistance that can also be found in the pathogenic bacteria.

The structure of mer-operons is different for each type of bacteria (Barkay et al., 2003). The key genes of the mer-operon are merA (gene reductase), mer $\mathrm{T}$ (transport protein gene), merP (extracellular mercury-binding protein gene) and merR (regulatory protein gene). However, operons can contain additional genes, such as mer $\mathrm{B}$ (organomercurial lyase gene), merC (transport protein gene), merD (regulatory protein gene), merE (transport protein gene), merF (transport protein gene) and $m e r \mathrm{G}$ (a gene that provides resistance to phenyl mercury) (Ianieva, 2009). The bacteria that possess only the mercury reductase (merA) gene are called narrow spectrum mercury

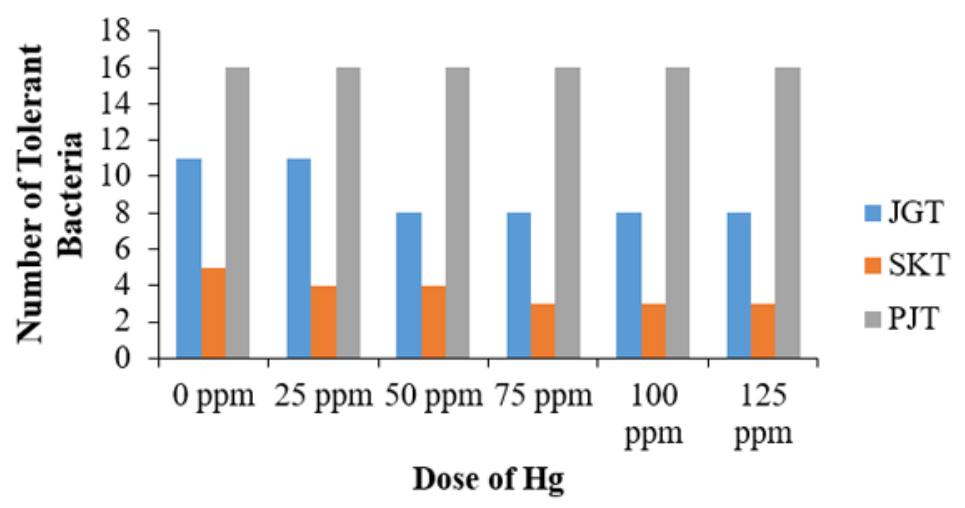

Figure 2. The ability of isolated bacteria to tolerate Hg. JGT: Jonggat; SKT: Sekotong; PJT: Pujut 
resistant bacteria. Some bacteria that have genes other than merA or merB are called broad-spectrum mercury resistant bacteria. The MerA protein has the function of reducing the toxic mercury ions to mercury $(\mathrm{Hg}(0))$ which is less toxic and volatile at room temperature. The MerB protein has the function of catalyzing the breaking of mercury-carbon bonds to produce organic compounds and $\mathrm{Hg}$ (II) ions (Barkay et al., 2003).

The ability of bacteria to transmit the resistance-coding genes or tolerance to the pathogenic bacteria causes a high potential for obtaining these bacteria during isolation. Reducing the potential use of pathogenic bacteria for the next stage of this stydy was carried out by testing the ability of blood hemolysis or pathogenicity tests. The results of the pathogenicity tests showed that 15 of the 27 isolates obtained were capable of the blood hemolysis. The ability of hemolysis is demonstrated by the formation of clear zones ( $\beta$ hemolysis) or changes in the color of the media ( $\alpha$ hemolysis) to green or brown around the bacterial colony (Buxton, 2016). There were 12 bacterial isolates that were unable to hemolyze blood ( $\gamma$ hemolysis) (Figure 3). Escherichia coli is a pathogenic bacterium that is known to be resistant to $\mathrm{Hg}$. E. coli is known to be able to store the $\mathrm{Hg}$ resistant genetic markers that make this bacterial species a promising alternative to the bioremediation process (Costa et al., 2013). In addition, E. coli also passed the test using it as a $\mathrm{Hg}$ resistant transgenic bacteria (Irawati et al., 2013).

\section{Bioaccumulation of $\mathrm{Hg}$ by isolated bacteria}

The bacterial isolate with the highest Hg bioaccumulation ability was JGT-F2 $(89.56 \%)$, followed by SKT-B (82.25\%) and JGT-F1 (81.21\%)
(Figure 4). Two bacteria with the highest $\mathrm{Hg}$ bioaccumulation ability were obtained from the Jonggat District tailings having the highest $\mathrm{Hg}$ concentration. One bacterial isolate with the highest ability to accumulate $\mathrm{Hg}$ was obtained from the Sekotong district tailings having the secondhighest $\mathrm{Hg}$ concentration. In addition, the three highest accumulator bacteria also had the best ability to adapt to $\mathrm{Hg}$ in the test media. Figure 5 shows that JGT-F2, SKT-B, and JGT-F1 isolates were able to adapt quickly, and their growth was quite stable on LB + Hg media compared to other isolates. This shows that the higher the $\mathrm{Hg}$ concentration in a soil, the greater the ability of bacteria to adapt to toxic metals.

The differences in the ability of bacteria to accumulate $\mathrm{Hg}$ are caused not only by the differences in the $\mathrm{Hg}$ concentrations in their habitats but also by the differences in the response mechanisms. The mechanism of bacterial response to high $\mathrm{Hg}$ in the environment is done in three ways, namely: (1) by inhibiting cell metabolism so that cells grow slowly, even dying, (2) inducing an operon system that plays a role in $\mathrm{Hg}$ resistance so that cells remain alive under stress, and (3) having a plasmid containing the $\mathrm{Hg}$ resistance genes (Ekyastuti and Setyawati, 2015). In the $\mathrm{Hg}$ resistant and $\mathrm{Hg}$ accumulator bacteria, $\mathrm{Hg}$ in the soil is transported across the lipid membrane that surrounds the cell. The absorption of $\mathrm{Hg}$ by bacteria is a crucial step in bioaccumulation. Most metals enter cells through special transmembrane cation transporters or through other metal transporters. Hg at high concentrations is transported by bacteria through protein transport or Mer T, whereas at low concentrations, $\mathrm{Hg}$ is absorbed through the lipid membrane in the form of water-soluble $\mathrm{Hg}$. The chemical bonds

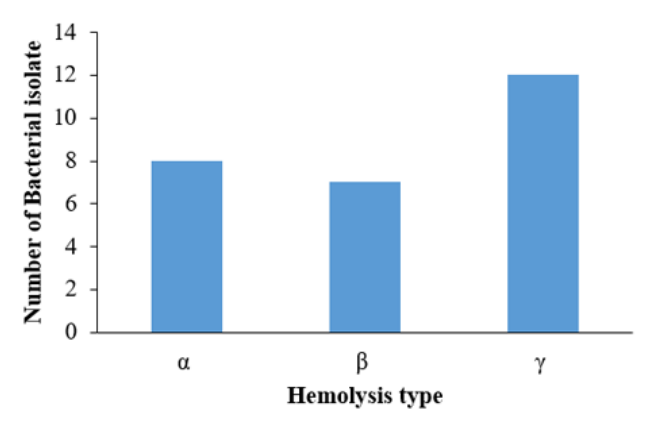

a)

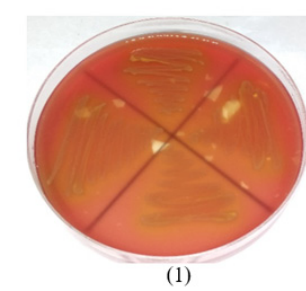

(1)

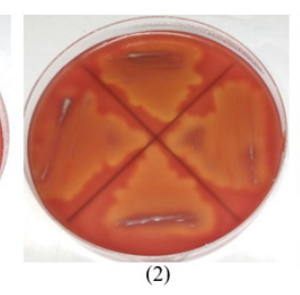

b)

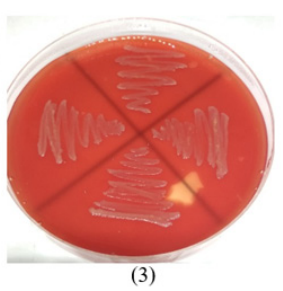

(3)

Figure 3. The blood hemolysis ability of the isolated bacteria. a) the number of bacteria based on the ability of hemolysis. b) the appearance of bacterial hemolysis in the Blood agar media, (1) $\beta$ hemolysis, (2) $\alpha$ hemolysis, (3) $\alpha$ hemolysis 


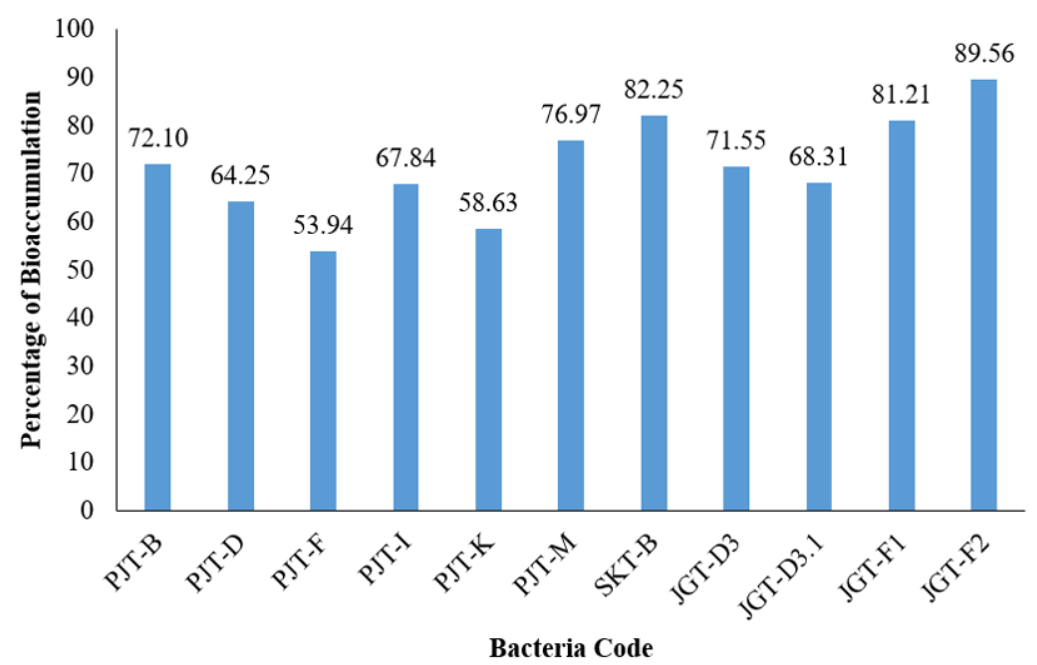

Figure 4. The ability of bioaccumulation of bacterial isolates on Luria Bertani Broth enriched Hg

in the $\mathrm{HgCl}_{2}$ complex are mostly covalent rather than ionic, so the complexes are relatively nonpolar in charge and have sufficient fat solubility. Fat solubility is generally measured by the octanol-water partition coefficient, which measures the relative solubility of a compound in octanol and water and ranging from almost zero for very hydrophilic molecules to 108 for highly hydrophobic (Morel et al., 1998).

The pattern of bacterial cell growth rate is influenced by the characteristics of individual bacterial cells. The bacterial growth on the media containing heavy metals is influenced by the type of bacteria and the effect of heavy metals on bacterial cells. Different bacterial species have various tolerance abilities, which are caused by the toxic properties of $\mathrm{Hg}$ and the strength of bacterial affinity for chelating agents in cells such as proteins, lipids and nucleic acids (Ekyastuti and Setyawati, 2015).

\section{Identification of $\mathrm{Hg}$ bioaccumulator bacteria}

The results of bacterial identification showed that the JGT-F1 is Basillus toyonensis (Figure 6), and the SKT-B is Fictibacillus nanhaiensis (Figure 7). However, the identification results also showed that the JGT-F2 was not a pure isolate, so the isolate was eliminated from the list of bacteria with the best ability. The two best bacteria were identified as gram-negative bacteria in the form of rod (bacilli) (Table 3).

The operons in Gram-negative bacteria can encode some proteins. This is not found in the

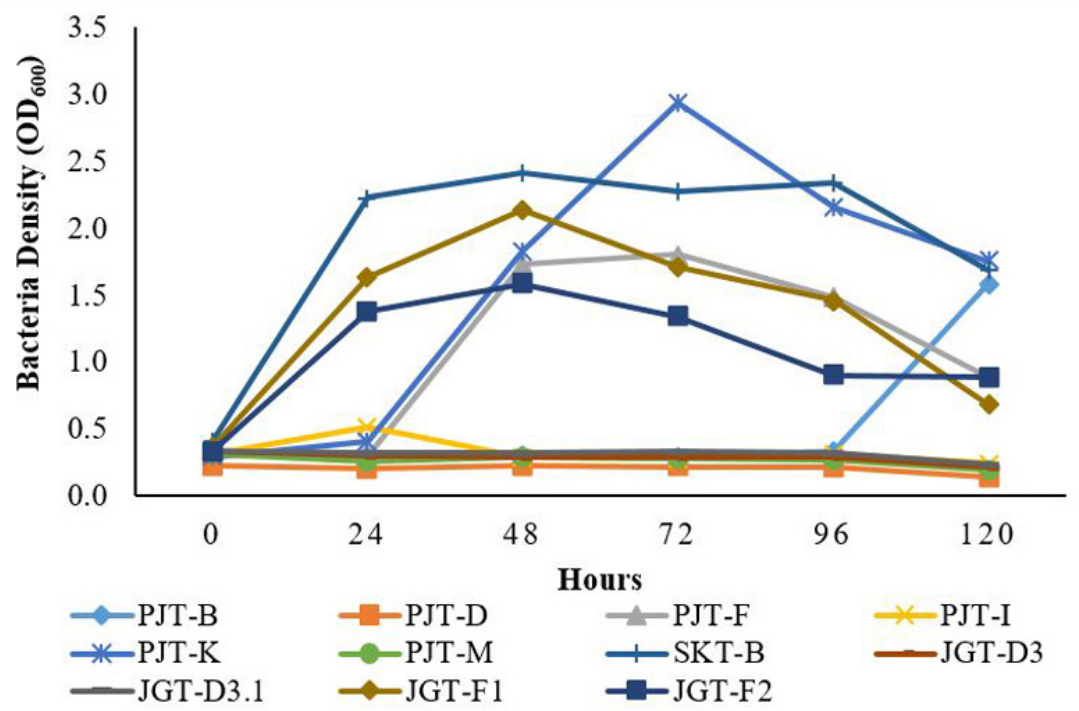

Figure 5. The growth curve of bacterial isolates on Luria Bertani Broth enriched with $\mathrm{Hg}$ 


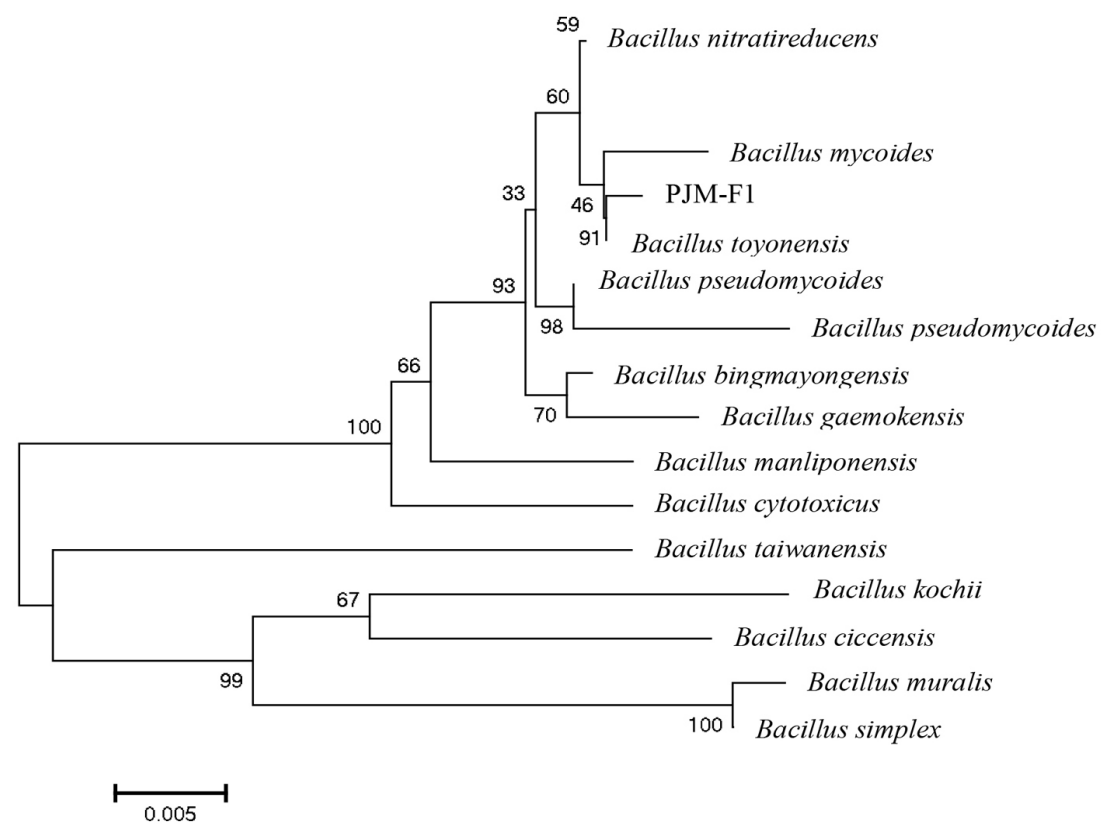

Figure 6. Phylogenetic tree of JGT-F1

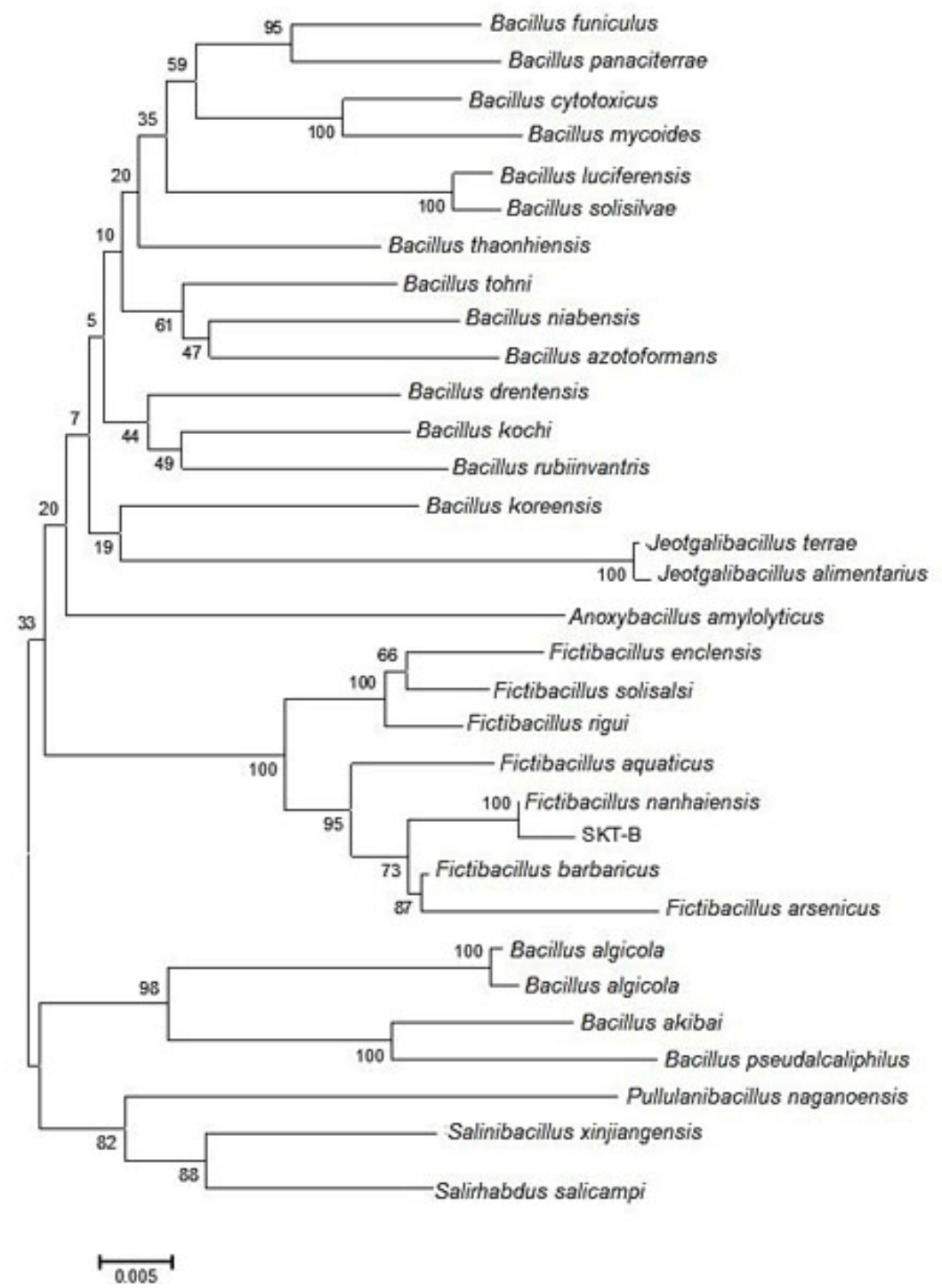

Figure 7. Phylogenetic tree of SKT-B 
gram-positive bacterial operons. Some of them are membrane proteins or $\operatorname{Mer} \mathrm{C}$, as well as $M e r \mathrm{~F}$ and MerE. MerE and MerF, which replace MerC in several operons, can work alone in the absorption of Hg (II), except mer on Thiobacilli, which is always known to be replaced by MerT. Periplasmic protein $(\mathrm{Mer} \mathrm{G})$ is also found in some Gram-negative bacteria. This protein gives a slight increase in the organomercurial resistance, even in strains that lack MerB. This causes that in many Gram-negative bacteria there is an additional protein called MerD, which appears to be hostile to the MerR activation for the transcription of mer-operons (Barkay et al., 2003).

\section{CONCLUSION}

The bacteria isolated from Pujut, Sekotong, and Jonggat Districts in Lombok Island, West Nusa Tenggara, were able to accumulate $\mathrm{Hg}$ with bioaccumulation capabilities of $53.94-89.56 \%$. The bacteria found can be used as remediation agents for tailings so that the contamination of $\mathrm{Hg}$ from tailings can be reduced. Exploration of the ability of bacteria needs to be carried out further to find out the extent of the ability of bacteria to accumulate $\mathrm{Hg}$ and its mechanism.

\section{Acknowledgements}

The authors thank the Directorate General of Higher Education of Indonesia for supporting the study through PMDSU scholarship scheme. Very valuable technical assistance and support from the staff of Biology Laboratory, Faculty of Mathematics and Natural Sciences, Brawijaya University are highly appreciated.

\section{REFERENCES}

1. Affinnih, K.O., Salawu, I.S., Isah, A.S. 2014. Methods of available potassium assessment in selected soils of Kwara State, Nigeria. Agrosearch, 14(1), 76-87. http://dx.doi.org/10.4314/agrosh.v14i1.8.

2. Araujo, A., Leite, L., De Iwata, B., De Lira, M., Xavier, G. M. Do Figueiredo .2012. Microbiological process in agroforestry systems: a review. Agronomy for Sustainable Development, 32(1), 215-226. doi: 10.1007/s13593-011-0026-0.

3. Barkay, T., Miller, S.M., Summers, A.O. 2003. Bacterial mercury resistance from atoms to ecosystems. FEMS Microbiology Reviews, 27(2-3), 355-384. doi: 10.1016/S0168-6445(03)00046-9.

4. Basu, N., Clarke, E., Green, A., Tagoe, B.C., Chan, L., Dzodzomenyo, M., Fobil, J., Long, R.N., Neitzel, R.L., Obiri, S., Odei, E., Ovadje, L., Quansah, R., Rajaeeand, M., Wilson, M.L. 2015. Integrated assessment of artisanal and small-scale gold mining in Ghana-Part 1: Human Health Review. International Journal of Environmental Research and Public Health, 12(5), 5143-5176. doi: 10.3390/ ijerph120505143.

5. Buxton, R. 2016. Blood Agar Plates and Hemolysis Protocols. American Society for Microbiology.

6. Cappuccino, J., Welsh, C. 2017. Microbiology: A Laboratory Manual. Microbiology Eleventh edition. Pearson, Harlow.

7. Chasanah, U., Nuraini, Y., Handayanto, E. 2018. The Potential of mercury-resistant bacteria isolated from small-scale gold mine tailings for accumulation of mercury. Journal of Ecological Engineering, 19(2), 236-245. doi: 10.12911/22998993/83565.

8. Costa, R., Gomes, K.M., Duarte, R.S., da Costa Rachid, C.T.C., Rosado, A.S., Mangia, A.H.R. 2013. Diversity of Mercury resistant Escherichia coli strains isolated from aquatic systems in Rio de Janeiro, Brazil. International Journal of Biodiversity, 2013(265356), 1-8.

9. Ekyastuti, W. and Setyawati, T. R. 2015. Identification and In Vitro Effectiveness Test of Four Isolates of Mercury-Resistant Bacteria as Bioaccumulation Agents of Mercury. Procedia Environmental Sciences, 28(1), 258-264. doi: 10.1016/j. proenv.2015.07.033.

10. Epstein, W. 2003. The roles and regulation of potassium in bacteria. Progress in Nucleic Acid Research and Molecular Biology, 75(1), 293-320

11. Fagorzi, C., Del Duca, S., Venturi, S., Chiellini, C., Bacci, G., Fani, R., Tassi, F. 2019. Bacterial Communities from extreme environments?: Vulcano Island. Diversity, 11(140), 1-17. doi: 10.3390/ d11080140.

12. Husen, E., Simanungkalit, R.D.M., Saraswati, R. 2007. Metode Analisis Biologi Tanah. Balai Besar Penelitian dan Pengembangan Sumberdaya Lahan Pertanian, Bogor, Indonesia.

13. Ianieva, O. 2009. Mechanisms of bacteria resistance to heavy metals. Mikrobiolohichny? Zhurnal, 71(6), 54-65.

14. Irawati, W., Patricia, Soraya, Y., Baskoro, A.H. 2013. A Study on mercury-resistant bacteria isolated from a gold mine in Pongkor Village, Bogor, Indonesia. HAYATI Journal of Biosciences, 19(4), 197-200. doi: 10.4308/hjb.19.4.197.

15. Kahl, G. 2015. Methylation Variable Position (MVP). The Dictionary of Genomics, Transcriptomics and Proteomics. Nova Science Publishers, Inc. doi: 10.1002/9783527678679.dg07434. 
16. Kjeldahl, J. 1883. Neue Methode zur Bestimmung des Stickstoffs in organischen Körpern (in German). Fresenius, Zeitschrift. Analytical Chemiecal, 22(1), 366-382. https://doi.org/10.1007/BF01338151

17. Krisnayanti, B.D. 2018. ASGM Status in West Nusa Tenggara Province, Indonesia. Journal of Degraded and Mining Lands Management, 5(2), 1077-1084. doi: 10.15243/jdmlm.2018.052.1077.

18. Krisnayanti, B.D., Anderson, C.W.N., Utomo, W.H., Feng, X., Handayanto, E., Muddarisna, N., Ikram, H., Khususiah. 2012. Assessment of environmental mercury discharge at a four-year-old artisanal gold mining area on Lombok Island, Indonesia. Journal of Environmental Monitoring, 14(10), 2598-2607. doi: 10.1039/c2em30515a.

19. Kuterbekov, K. 2019. Environmental Monitoring at A Former Uranium Milling Site. Springer Nature, Switzerland

20. Lay, B.W., Hastowo, S. 1992. Mikrobiologi. Rajawali Pers, Jakarta.

21. Ma?uszy?ski, M.J., D?browski, P., Ma?uszy?ska, I. 2019. Mercury content in upper layers of soils from the areas with various impacts of anthropogenic pressure. Journal of Ecological Engineering, 20(11), 13-17. https://doi.org/10.12911/22998993/113416

22. Moore, E.W. 1968. Determination of $\mathrm{pH}$ by the glass electrode: $\mathrm{pH}$ Meter Calibration for Gastric Analysis. Gastroenterology, 54(4), 501-507.

23. Morel, F.M.M., Kraepiel, A.M.L., Amyot, M. 1998. The chemical cycle and bioaccumulation of mercury. Annual Review Ecology System, 29(1), 543-566. doi: 10.1146/annurev.ecolsys.29.1.543.

24. Muddarisna, N., Krisnayanti, B.D., Utami, S.R., a Handayanto, E. 2013. The potential of wild plants for phytoremediation of soil contaminated with mercury of gold cyanidation tailings. IOSR Journal of Environmental Science, Toxicology and Food Technology, 4(1), 15-19. doi: 10.9790/2402-0411519.

25. Muller, A.K., Westergaard, K., Christense, S., SÖrensen, S.J. 2001. The Effect f long-term mercury pollution on the soil microbial community. FEMS Microbiology Ecology, 36(2001), 10-19. doi: 10.1111/j.1574-6941.2001.tb00821.x.

26. Ojuederie, O.B., Babalola, O.O. 2017. Microbial and Plant-assisted bioremediation of heavy metal polluted environments: a review. International Journal of Environmental Research and Public Health, 14(12), 1-26. doi: 10.3390/ijerph14121504.

27. Olsen, S.R., Cole, C.V., Watanabe, F.S., Dean, L.A. 1954. Estimation of available phosphorus in soils by extraction with sodium bicarbonate. Circular, 939, 19.

28. Puspitasari, R. 2007. Laju polutan dalam ekosistem laut. Oseana, 32(2), 21-28. doi: 10.1007/ s11695-013-0950-y.

29. Rao, N.S.S. 1977. Soil microorganisms and plant growth. Oxford and IBH Publishing, New Delhi, India.

30. Rasmussen, L.D., Zawadsky, C., Binnerup, S.J., Øregaard, G., Sørensen, S.J., Kroer, N. 2008. Cultivation of hard-to-culture subsurface mercury-resistant bacteria and discovery of new merA gene sequences. Applied and Environmental Microbiology, 74(12), 3795-3803. doi: 10.1128/AEM.00049-08.

31. Sanjay, M.S., Sudarsanam, D., Raj, G.A., Baskar, K. 2018. Isolation and identification of chromium reducing bacteria from tannery effluent. Journal of King Saud University-Science, 32(1), 265-271. doi: 10.1016/j.jksus.2018.05.001.

32. Subandi. 2014. Mikrobiologi. Bandung. Remaja Rosdakarya

33. Tjahjono, A., Suwarno, D. 2018. The spatial distribution of heavy metal lead and cadmium pollution and coliform abundance of waters and surface sediment in Demak. Journal of Ecological Engineering, 19(4), 43-54. https://doi.org/10.12911/22998993/89715

34. Utomo, W.H., Suntari, R., Arfarita, N., Suhartini, Handayanto, E. 2014. Rehabilitation of artisanal small-scale gold mining land in West Lombok, Indonesia: 3. Exploration of indigenous plant species and the associated mycorrhiza for phytomycoremediation of mercury contaminated soils. American-Eurasian Journal of Sustainable Agriculture, 8(1), 34-41.

35. Walkley, A., Black, I.A. 1934 An examination of the Degtjareff Method for determining soil organic matter and a proposed modification of the chromic acid titration method. Soil Science, 37(1), 29-38. http:// dx.doi.org/10.1097/00010694-193401000-00003

36. Waxman, S.A., Stevens, K.R. 1930. A critical study of the methods for determining the nature and abundance of soil organic matter. Soil Science, 30(1), 97-116. 